\title{
EDITORIAL
}

\section{The Ethical Issue of Others}

\author{
Ulrika Mårtensson
}

This issue of Comparative Islamic Studies contains three articles and three book reviews that illustrate the journal's aim to show how theoretically grounded analysis of Islam contributes to the general study of religions, and how scholarly disciplines shape the knowledge a study produces. The two first articles continue topics introduced in previous issues, while the third one introduces a new field of enquiry for this journal. They share, however, a preoccupation with the role of religion in the drawing of boundaries, and the ethical implications thereof.

Michael Wesley Graves, "The Upraised Mountain and Israel's Election in the Qur'an and Talmud," continues the comparative focus that Abdulla Galadari developed in his article in issue 9.2 (2013), namely tracing Biblical and Talmudic motifs in the Qur'an. Graves' study focuses on the Biblical topic of Moses and the Israelites at Mt. Sinai (Ex. 19:17), and its exegesis in the Babylonian Talmud, and in the Qur'an. Both in the Talmud and in the Qur'an, the exegesis dwells on the issue of God's election of Israel, and its implications for relations with other communities. Graves makes the case that the different styles of the Talmud and the Qur'an - the former rather non-polemical and the latter rather polemical reflect the difference between the "mature" and probative Talmudic scholarly discourse, with its long history of interactions with other religious communities, and the "novel" Qur'an, whose sharp boundaries between believers and nonbelievers typify a "new religious movement." This established Religious studies term that some have applied to pre-modern cases has not been much used in the study of early Islam, but it has the potential to yield interesting results. Moreover, Graves' comparison contributes both to such burgeoning fields as the Qur'an's literary context, and potentially to Talmud research: to what extent was the Qur'an and Islam significant for the development of the Babylonian Talmud, which according to some recent studies carried on into the 700s?

To the extent that the Qur'an's boundaries are sharp, this trait can also be seen as constitutive of its identity as canon, a genre designed to define a com-

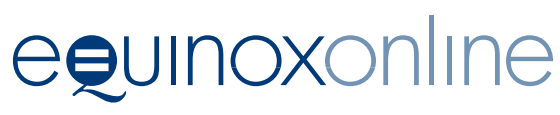


munity by distinguishing it from its "others." However, as scholarly exegesis proceeds and schools establish, boundaries of theology and ethics emerge within the community, as well as towards the external others. Several previously published articles in CIS explore how Islamic concepts and ethics can inspire reflection on current social and political challenges bearing on this topic; these include the studies by Wardah Alkatiri $(10.2,2014)$, Haris A. Durrani $(10.1,2014)$, and perhaps in this case especially Clinton Bennet's and Sarwar Alam's special issue on Sufism, Pluralism and Democracy (9.1, 2013). Here, Faraz Masood Sheikh contributes with a study from a place and time when the Islamic scholarly disciplines are in their first blossom, namely the religiously diverse Abbasid capital Baghdad in the 200s/800s: "Encountering Opposed Others and Countering Suggestions (khatarāt): Notes on Religious Tolerance from Ninth Century Arab-Muslim Thought." In focus is al-Ḥārith b. Asad al-Muhāsibī (d. 242/857), one of the most influential early scholars and ethicists, working within the episteme that later defined the Ash'arite school of theology (kaläm). Sheikh expounds what he perceives as al-Muhāsibī's ethics of tolerance, with reference to the current field of "Comparative Religious Ethics," particularly concepts of tolerance as requiring restraint from imposing one's own favoured view or course of action on "disliked others," out of respect for their right to make choices. While al-Muhāsibī ends up with an ethical attitude of humility towards "disliked others," his route there goes via a theology of God's absolute freedom and rights, and human enslavement to God. God commands the believer to hate and condemn the unbeliever, at the same time as true recognition of the human condition of enslavement must lead to the realisation that God alone has the power to grant or withhold belief. Ethically, Sheikh argues, al-Muhāsibī's theology requires the believer to experience humility towards the unbeliever and insecurity regarding the own belief and one's own merits, since both unbelief and belief result from God's absolute right and freedom of choice.

In the third article, Anthony Heath, Yaojun Li, and Tom Woerner-Powell treat a very different subject: "Trapped in Poverty?-A study of transient and persisting factors for Muslim disadvantages in the UK." The discipline is Sociology and quantitative method, applied to the field of social inequalities, and the analytical categories "religion" and "bonding and bridging social capital." Comparison is thus between religiously defined groups within the British people, with a focus on economy, using data from the UK Household Longitudinal Study. The data shows Muslims are significantly more vulnerable to poverty than other groups. The most important identifiable persisting factor is "bridging social capital," i.e. networks and connections outside of one's own group, as distinct from "bonding social capital," i.e. connections within a group. Compared with especially Anglicans, Muslims "bridging capital" is less protecting against pov-

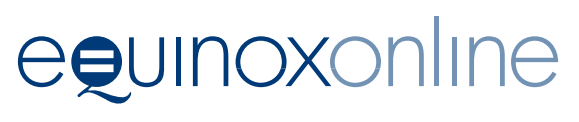


erty, suggesting for further research that social class and stratified labour market determines the economic outcomes from bridging capital. Muslims may thus be exemplarily engaged in cross-communal civil activities, without that increasing their economic wellbeing because of their relatively economically weak networks. Muslims are also poorer than other religious groups with the same ethnic and class backgrounds. The authors suggest this could be due to discrimination in the wake of the "war on terror" and the negative publicity surrounding Islam and Muslims, and they recommend further research into this problem.

The final word is to thank all the contributors to this issue: the authors for choosing CIS; Martin Riexinger for the book reviews; the anonymous reviewers for their careful readings and constructive criticism; Russell Adams at Queenston Publishing for production and editing; Ailsa Parkins for editorial assistance and guidance; and Janet Joyce for generous advice, and for the opportunity.

(c) Equinox Publishing Ltd. 2018

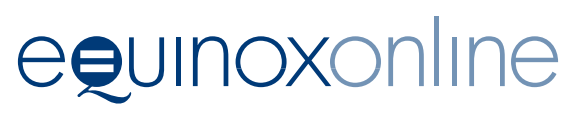

